\title{
Comparison of the impact of allelic polymorphisms in PfAMA1 on the induction of T Cell responses in high and low malaria endemic communities in Ghana
}

\author{
Ebenezer A. Ofori ${ }^{1,2}$, John K. A. Tetteh ${ }^{2}$, Augustina Frimpong ${ }^{2}$, Harini Ganeshan ${ }^{3,5}$, Maria Belmonte ${ }^{3,5}$, \\ Bjoern Peters ${ }^{4}$, Eileen Villasante ${ }^{3}$, Martha Sedegah ${ }^{3}$, Michael F. Ofori ${ }^{1,2}$ and Kwadwo A. Kusi ${ }^{1,2^{*}}$ (i)
}

\begin{abstract}
Background: Malaria eradication requires a combined effort involving all available control tools, and these efforts would be complemented by an effective vaccine. The antigen targets of immune responses may show polymorphisms that can undermine their recognition by immune effectors and hence render vaccines based on antigens from a single parasite variant ineffective against other variants. This study compared the influence of allelic polymorphisms in Plasmodium falciparum apical membrane antigen 1 (PfAMA1) peptide sequences from three strains of $P$. falciparum (3D7, 7G8 and FVO) on their function as immunodominant targets of T cell responses in high and low malaria transmission communities in Ghana.

Methods: Peripheral blood mononuclear cells (PBMCs) from 10 subjects from a high transmission area (Obom) and 10 subjects from a low transmission area (Legon) were tested against 15 predicted CD8 + T cell minimal epitopes within the PfAMA1 antigen of multiple parasite strains using IFN- $\gamma$ ELISpot assay. The peptides were also tested in similar assays against CD8 + enriched PBMC fractions from the same subjects in an effort to characterize the responding $T$ cell subsets.
\end{abstract}

Results: In assays using unfractionated PBMCs, two subjects from the high transmission area, Obom, responded positively to four (26.7\%) of the 15 tested peptides. None of the Legon subject PBMCs yielded positive peptide responses using unfractionated PBMCs. In assays with CD8 + enriched PBMCs, three subjects from Obom made positive recall responses to six (40\%) of the 15 tested peptides, while only one subject from Legon made a positive recall response to a single peptide. Overall, 5 of the 20 study subjects who had positive peptide-specific IFN- $\gamma$ recall responses were from the high transmission area, Obom. Furthermore, while subjects from Obom responded to peptides in PfAMA1 from multiple parasite strains, one subject from Legon responded to a peptide from 3D7 strain only.

Conclusions: The current data demonstrate the possibility of a real effect of PfAMA1 polymorphisms on the induction of T cell responses in malaria exposed subjects, and this effect may be more pronounced in communities with higher parasite exposure.

\footnotetext{
*Correspondence: Akusi@noguchi.ug.edu.gh

${ }^{1}$ West Africa Centre for Cell Biology of Infectious Pathogens, Department of Biochemistry, Cell and Molecular Biology, College of Basic and Applied Sciences, University of Ghana, Legon, Accra, Ghana

Full list of author information is available at the end of the article
} permits use, sharing, adaptation, distribution and reproduction in any medium or format, as long as you give appropriate credit to the original author(s) and the source, provide a link to the Creative Commons licence, and indicate if changes were made. The images or other third party material in this article are included in the article's Creative Commons licence, unless indicated otherwise in a credit line to the material. If material is not included in the article's Creative Commons licence and your intended use is not permitted by statutory regulation or exceeds the permitted use, you will need to obtain permission directly from the copyright holder. To view a copy of this licence, visit http://creativecommons.org/licenses/by/4.0/. The Creative Commons Public Domain Dedication waiver (http://creativeco mmons.org/publicdomain/zero/1.0/) applies to the data made available in this article, unless otherwise stated in a credit line to the data. 
Keywords: Malaria, T cells, IFN- $\gamma$ ELISpot, Ghana, Apical membrane antigen 1 (PfAMA1)

\section{Introduction}

Malaria is a deadly vector-borne tropical disease of great public health concern. The disease is caused by the apicomplexan parasite Plasmodium, which is transmitted through the bite of an infected female Anopheles mosquito during a blood meal. With the increase in the number of existing tools recommended by the World Health Organization (WHO) for malaria control, malaria-related deaths have decreased over the last two decades in subSaharan Africa [1]. However, with these interventions in place, people, including children and adults, are still getting sick and dying from malaria. Hence, WHO has recommended the development of new interventions including vaccines to reinforce our hope of eradicating the disease [2]. RTS,S/AS01E (Mosquirix ${ }^{\mathrm{TM}}$ ) is the first and only malaria vaccine to date to demonstrate protection against malaria in children in phase 3 clinical trials [3]. However, its efficacy has been reported to wane with time [4] and this needs to be addressed in order to stay on track to meet the malaria eradication goal. Alternative vaccine design strategies are being explored for the development of more efficacious vaccines.

An effective malaria vaccine should be capable of inducing protective immune responses against variant forms of the parasite and in a genetically diverse population. Plasmodium falciparum apical membrane antigen 1 (PfAMA1) has been investigated as a vaccine candidate in several clinical trials [5-8]. PfAMA1 is found in the sporozoite, liver, and blood stages of the parasite [9] and therefore represents a multi-target antigen for vaccine development. It has been shown to be a target of both antibody $[6,10,11]$ and $T$ cell $[12-16]$ responses. Antibodies to PfAMA1 have been demonstrated to inhibit red blood cell invasion by merozoites [17].

In populations with high malaria endemicity, there is a measured high meiotic recombination rate and nucleotide substitutions in P. falciparum and these have been associated with increased drug and immune pressure on the parasites $[18,19]$. For PfAMA1, multiple nucleotide substitutions within the protein sequence result in the formation of allelic or polymorphic forms of the antigen in different parasite variants. As a direct result of these polymorphisms, antibodies to one allelic form of PfAMA1 have been reported to bind less with other PfAMA1 alleles because a substantial fraction of antibodies are towards strain-specific epitopes [17, 20]. While the effect of antigen polymorphisms has been clearly demonstrated for antibody responses, there is much less data on whether there is a similar effect of polymorphism on $\mathrm{T}$ cell recognition of epitopes within polymorphic antigens such as PfAMA1. Sedegah et al. [21] have investigated the effect of single amino acid substitutions in immunodominant PfAMA1 allelic epitopes on $\mathrm{T}$ cell response induction and report a significant effect of these single amino acid substitutions on TCR recognition of peptide-MHC complexes, and hence IFN- $\gamma$ induction.

$\mathrm{T}$ cells are classically stimulated in the context of major histocompatibility complex (MHC) molecules and are known to bind to specific amino acid residues on the peptide sequence [22]. Furthermore, $\mathrm{T}$ cell receptors (TCRs) are typically known to interact with both the MHC molecules and the peptides being presented by the MHC molecules through specific residue identification [23-25]. MHC genes are amongst the most diverse human genes with thousands of variants within any population [26]. Hence, polymorphism within the peptides and/or within the MHC molecule will most likely affect MHC binding and TCR recognition [27]. This study therefore investigated the impact of allelic polymorphisms in selected PfAMA1 peptide sequences from three strains of $P$. falciparum (3D7, 7G8 and FVO) on their function as targets of immunodominant $\mathrm{T}$ cell responses in high and low malaria transmission communities in southern Ghana.

\section{Methods}

\section{Study communities and population}

This cross-sectional study was conducted in two separate locations within the Greater Accra region of Ghana with different malaria transmission intensities; Obom is a high transmission community while Legon is a low malaria transmission community. Obom is in the GaSouth Municipality of Greater Accra Region of Ghana with a population of about 296,552 as projected in the 2018-2021 Revised Medium Term Development Plan [28]. Malaria transmission in Obom is perennial but the peak malaria season coincides with the main rainy season between June and August. The average yearly rainfall ranges between 790 to $1270 \mathrm{~mm}$ [29]. In 2018, malaria incidence by microscopy was $35.6 \%$ of all out-patient visits at the Obom Health Centre [30]. On the other hand, Legon is in the Ayawaso West municipality of the Greater Accra Region, with an estimated population of about 100,000 persons. In Legon, malaria transmission follows the rainfall pattern seen between May and June and the average annual rainfall is around $810 \mathrm{~mm}$ [31]. Malaria slide positivity is usually below $1 \%$ for most of the year [32]. The prevalence of $P$. falciparum is therefore higher in Obom compared to Legon [33]. 


\section{Subjects, sample collection and processing}

Eligibility criteria for participation in the study were being between the ages of 18 and 50 years, not being pregnant or nursing for females and not being anaemic (Hb levels above $10 \mathrm{~g} / \mathrm{dl}$ ). Enrolled subjects had a normal medical history after screening. A total of 20 subjects, 10 from the high transmission area of Obom (s1 to s10) and another 10 from the low transmission area of Legon (s11 to s20) who met the inclusion criteria were recruited and screened for malaria parasites by rapid diagnostic test (RDT) kits and by light microscopy. Venous blood $(60 \mathrm{ml})$ was obtained from each subject by venipuncture into heparinized tubes using aseptic techniques. Peripheral blood mononuclear cells (PBMCs) were isolated from blood by gradient centrifugation using Ficoll-Paque separating medium. After washing and counting, the cells were cryo-preserved at 20 million per milliliter in freezing mix (consisting of 90\% FBS and 10\% DMSO) at $-80{ }^{\circ} \mathrm{C}$ overnight and transferred to liquid nitrogen until use for ELISpot assay. This study was conducted during the off peak/dry season (January, 2019), which has been reported to have significant reduction in parasite prevalence [29].

\section{Synthetic peptides selection}

A set of 15 peptides from a previously generated set of predicted high-affinity MHC class I binders from the 3D7 parasite clone PfAMA1 were selected for the present study. These selected peptides had some variant amino acid positions when compared to the corresponding PfAMA1 sequences from the FVO and 7G8 parasite strains (Table 1). All peptides were synthesized commercially by Chiron Technologies (Clayton, Victoria, Australia). The 15 PfAMA1 9-10mer peptides were grouped into six PfAMA1 peptide sets, with each set containing the variant corresponding peptides from the three different parasite strains.

Peptide sequences represent amino acid sequences deduced from variable regions of the PfAMA1 3D7 (consensus), FVO and 7G8 strains. Peptide binding predictions were made for the 3D7 sequence using the NetMHC algorithm $[34,35]$ and based on recognition by the indicated specific HLA types. Predictions were based on IC50 values being less than $500 \mathrm{nM}$. Variable position(s) in corresponding peptide sequences of parasite variants are boldened and underlined in the sequences.

\section{Characterization of ELISpot IFN- $\gamma$-producing cells by T cell subset depletions}

Subject-specific PBMCs were depleted of CD4+ T cells using anti-human CD4+antibody-coated Dynabeads (Depletion MyOne ${ }^{\mathrm{TM}}$ SA Dynabeads ${ }^{\circledR}$ Invitrogen, USA) following the manufacturer's instructions. Flow cytometry was used to confirm the efficiency of $\mathrm{CD} 4+$ cell subset depletion.

Table 1 PfAMA1 peptide allele sets used for PBMC stimulation

\begin{tabular}{|c|c|c|c|c|c|c|}
\hline Allelic set & Peptides & Sequence & Strain & $\begin{array}{l}\text { HLA allele predicted for the } \\
\text { 3D7 Pf variant peptide }\end{array}$ & HLA supertype & $\begin{array}{l}\text { Amino acid } \\
\text { residue } \\
\text { positions }\end{array}$ \\
\hline \multirow[t]{3}{*}{1} & e1 & AKDKLFENY & FVO & & & $278-286$ \\
\hline & e2 & AKDKSFQNY & $7 \mathrm{G} 8$ & & & $278-286$ \\
\hline & e3 & AKDISFQNY & $3 \mathrm{D} 7$ & HLA B*15:03 & B27 & $278-286$ \\
\hline \multirow[t]{2}{*}{2} & e22 & DVY $\underline{\text { HPINEHR }}$ & 7G8, FVO & & & $36-45$ \\
\hline & e23 & DVYRPINEHR & $3 \mathrm{D} 7$ & $A^{*} 68: 01$ & A03 & $36-45$ \\
\hline \multirow[t]{2}{*}{3} & e24 & EHREHS $\underline{\mathbf{S}} \mathrm{KEY}$ & $7 \mathrm{G} 8$ & & & $43-51$ \\
\hline & e25 & EHREHPKEY & 3D7, FVO & HLA B*15:03 & B27 & $43-51$ \\
\hline \multirow[t]{2}{*}{4} & e46 & $\underline{\mathbf{D}} F Y K \underline{N} N \underline{E} Y V K$ & 7G8, FVO & & & $200-209$ \\
\hline & e48 & HFYKDNKYVK & $3 \mathrm{D} 7$ & $A^{*} 68: 01$ & $\mathrm{~A} 03$ & $200-209$ \\
\hline \multirow[t]{3}{*}{5} & e60 & $\underline{\text { KLFENNYTYL }}$ & FVO & & & $282-290$ \\
\hline & e61 & $\underline{\text { KSFQNYTYL }}$ & $7 G 8$ & & & $282-290$ \\
\hline & e62 & ISFQNYTYL & $3 \mathrm{D} 7$ & $\begin{array}{l}A^{*} 02: 02 \\
B^{*} 15: 03 \\
B * 58: 01\end{array}$ & $\begin{array}{l}\mathrm{A} 02 \\
\mathrm{~B} 27 \\
\mathrm{~B} 58\end{array}$ & $282-290$ \\
\hline \multirow[t]{3}{*}{6} & e87 & MTLNGMRDFY & FVO & & & $193-202$ \\
\hline & e88 & 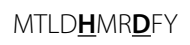 & $7 G 8$ & & & $193-202$ \\
\hline & e89 & MTLDEMRHFY & $3 \mathrm{D} 7$ & $\begin{array}{l}A * 30: 02 \\
A * 29: 02\end{array}$ & $\begin{array}{l}\mathrm{A} 01 \\
\mathrm{~A} 01 \mathrm{~A} 24\end{array}$ & $193-202$ \\
\hline
\end{tabular}




\section{Ex vivo ELISpot IFN- $\gamma$ Assay}

IFN- $\gamma$ ELISpot assay was performed as described earlier by $[15,36]$ using the unfractionated and CD8 + enriched PBMCs. Multiscreen plates (Millipore Corporation, USA) were coated with Monkey anti-human IFN- $\gamma$ antibodies (Mabtech AB, USA) and incubated overnight at $4{ }^{\circ} \mathrm{C}$. PBMCs $(400,000$ cells/well) from each subject were tested in duplicate with $10 \mu \mathrm{g} / \mathrm{ml}$ of each PfAMA1 peptide. Concanavalin A (Con A, Sigma Aldrich, USA) at a concentration of $1.25 \mu \mathrm{g} / \mathrm{ml}$ was used as a cell viability positive control. Subject PBMCs that were incubated with medium only were used as negative controls. After PBMC incubation for $36 \mathrm{~h}$, spots were detected by incubation with biotinylated anti-IFN- $\gamma$ polyclonal antibody (Mabtech, USA) and subsequently with alkaline-phosphatase-conjugated streptavidin (Mabtech, USA). After plate development with chromogenic substrate for alkaline phosphatase (Bio-Rad, USA) and plate drying, the number of IFN- $\gamma$ spots per well was counted using an automated Multispot plate reader (AID GmbH, Germany).

\section{Data analysis}

The data acquired were exported to Microsoft Excel and IFN- $\gamma$ activities of all peptides were calculated as the number of spot forming cells per million PBMCs $(\mathrm{sfc} / \mathrm{m})$. Response elicited by any peptide/stimulant was defined as positive based on our previously established thresholds $[15,36]$, which include (a) at least a doubling of $\mathrm{sfc} / \mathrm{m}$ in test wells compared to negative control wells, and (b) a difference of at least 10 spots between test and negative control wells. Statistical analysis and graphics were done using Graph Pad prism (version 6.0, San Diego, CA, USA) and Microsoft Excel 2013. Flow cytometry analysis was done using FlowJo V10 software (Tree Star, San Carlos, CA, USA).

\section{Results \\ Study participants}

A total of 20 study subjects (10 from each of the two sites) who met the eligibility requirements and gave informed consent participated in the study. Study subjects were aged between 18 and 35 years, with an average age of 29 years at Obom and 26 years at Legon. All female subjects tested negative for pregnancy and all subjects were negative for malaria parasites by light microscopy and malaria RDT. For each subject, the ELISpot activity $(\mathrm{sfc} / \mathrm{m})$ for the unstimulated medium control was subtracted from the activities $(\mathrm{sfc} / \mathrm{m})$ for peptide or Con A control-stimulated cells prior to analysis. A summary of data for the six study subjects who made at least one positive peptide response is presented as Additional file 1.

\section{Ex vivo ELISpot IFN- $\gamma$ responses from unfractionated PBMCs to variant PfAMA1 peptides}

The magnitude of IFN- $\gamma$ responses $(\mathrm{sfc} / \mathrm{m})$ from unfractionated PBMCs of two of the 20 study subjects following stimulation with 15 synthetic PfAMA1 minimal epitopes is shown in Fig. 1. Two subjects (s2 and s6) from the high transmission area (Obom) made positive responses to four of the 15 peptides tested. The first subject (s2) responded positively to a single peptide e25, [EHREHPKEY, (3D7/FVO)], with no positive response to the corresponding allelic variant peptide e24. (see Table 1). The second subject ( $\mathrm{s} 6$ ) responded to four of the 15 peptides tested (27\%). The four peptides were e3, e22, e24, and e25 [AKDISFQNY (3D7), DVYHPINEHR (7G8/FVO), EHREHSKEY (7G8) and EHREHPKEY (3D7/FVO)], respectively. Two of these positive peptides (EHREHSKEY and

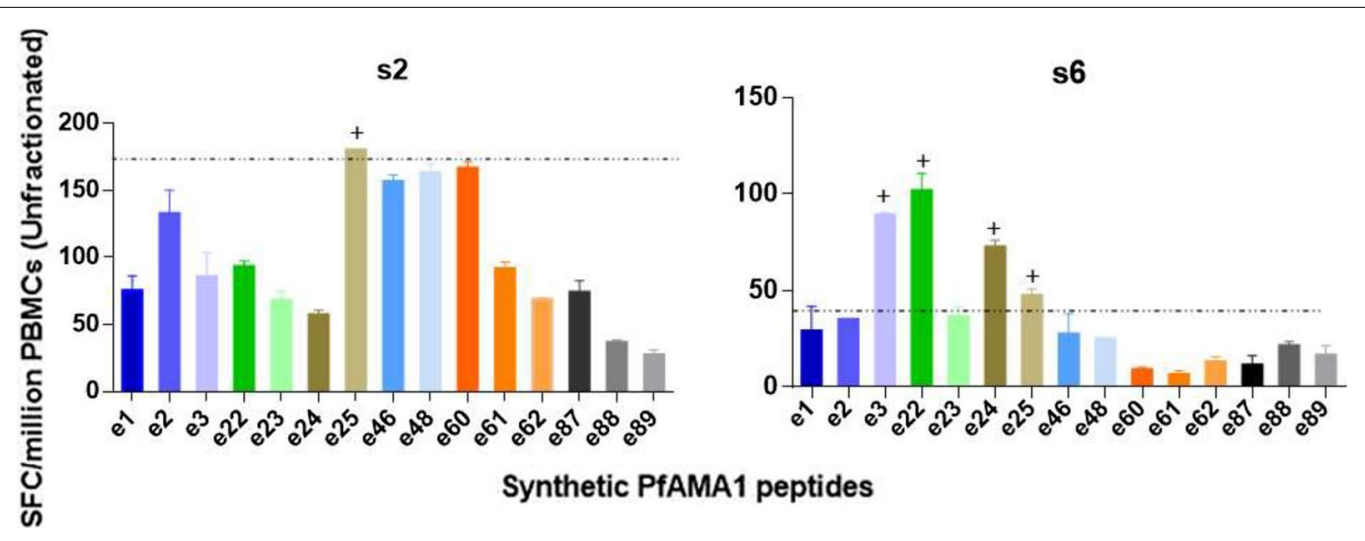

Fig. 1 IFN- $\gamma$ responses to variant PfAMA1 synthetic peptides in subjects $s 2$ and $s 6$. Responses are against unfractionated PBMCs. Allelic peptides are presented as different shades of the same colour. Dotted horizontal lines indicate the positivity cut-off based on the positive response definition, and peptides labelled with + are those that had positive IFN- $\gamma$ activity. SFC/million is Spot Forming Cells per million cells. 


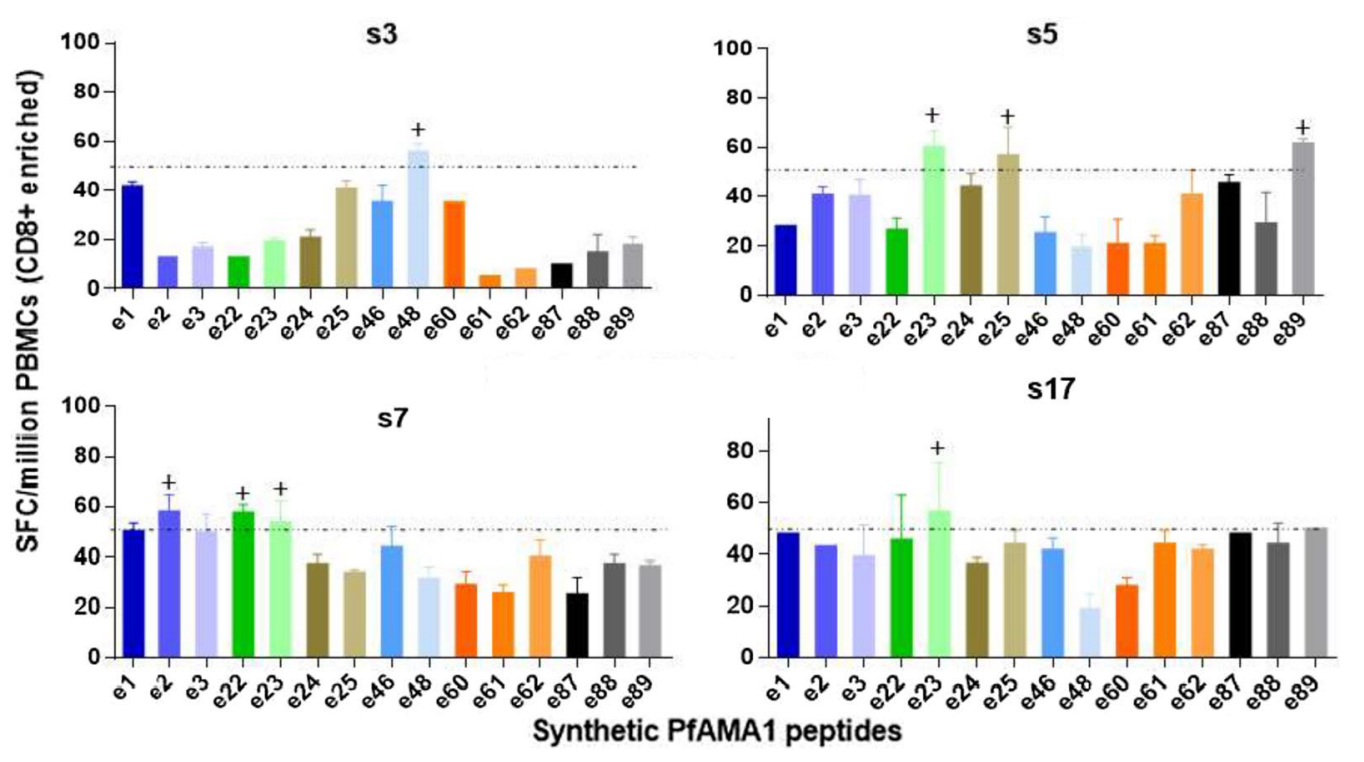

Fig. 2 PfAMA1 variant-specific IFN- $\gamma$ responses of CD8 + enriched PBMCs from study subjects. Allelic peptides are presented as different shades of the same colour. Dotted horizontal lines indicate the positivity cut-off based on the positive response definition, and peptides labelled with + are those that had positive IFN- $y$ activity. SFC/million is Spot Forming Cells per million cells.

EHREHPKEY) were variant peptides from different parasite strains. In the low transmission area, however, none of the subjects made positive responses to the 15 peptides tested based on the positivity criteria.

\section{CD8 + Enriched PBMCs IFN- $\gamma$ activities against synthetic peptides}

The CD $4+$ cell depletion protocol used achieved on average about $80 \%$ content of $\mathrm{CD} 8+\mathrm{T}$ cells in fractionated PBMCs (Additional file 2). The magnitude of IFN- $\gamma$ responses $(\mathrm{sfc} / \mathrm{m})$ from $\mathrm{CD} 8+$ enriched PBMCs against 15 synthetic PfAMA1 peptides is shown in Fig. 2. CD8+enriched PBMCs from three subjects from the high transmission area (Obom, s3, s5, s7) made seven positive responses to six peptides. Subjects s5 and s7 made positive responses to 3 peptides each, while subject s3 made a positive response to a single peptide [HFYKDNKYVK (3D7)]. However, in the low transmission area (Legon), CD8 + enriched PBMCs from subject s17 made a positive response to a single peptide [DVYRPINEHR (3D7)].

\section{Frequency of subjects' responses to predicted PfAMA1 variant peptides in the two study areas}

The frequency of variant peptide responses to study subjects are shown in Table 2. Generally, most of the peptides that recalled positive responses with subject PBMCs belonged to the 3D7 parasite clone. The five positive subjects from the high transmission area (Obom) and the single positive subject from the low transmission area (Legon) all responded to 3D7 peptides. Four of the five subjects from the high transmission area with positive 3D7 clone peptide responses also made positive responses to the variant peptides belonging to the other parasite strains, with $\mathrm{s} 3$ being the only subject that responded to a 3D7 peptide alone.

\section{Positions and frequency of amino acids substitutions}

Positions and frequencies of amino acids within peptides that made positive responses are shown in Fig. 3. A total of 14 amino acid substitutions were associated with positivity of the tested peptides and these occurred at seven different positions within the peptide's sequences. These were positions $1,2,4,5,6,7$ and 8 . A total of five substitutions occurred at position 4 , and this included substitution in the only peptide that tested positive in the low transmission area. Two substitutions occurred at each of positions 1, 5 and 6, and a single substitution occurred at each of positions 2,7 and 8 .

\section{Discussion}

$\mathrm{T}$ lymphocyte recognition of sequences within malaria antigens is an essential feature of the adaptive immune response for limiting Plasmodium infection in humans. Interferon-gamma (IFN- $\gamma$ ) is a key immune molecule that is secreted by parasite-specific activated $\mathrm{T}$ cells and has a liver stage parasite killing effect. Recognition of parasite antigen peptide-MHC complexes by $\mathrm{T}$ cells involves molecular interactions between amino acid residues on both the TCR and the parasite peptides, and 
Table 2 Parasite variant-specific responses at the two study sites

\begin{tabular}{|c|c|c|c|c|}
\hline Study site & Subject & PBMC fraction & Positive peptides & Parasite Strain \\
\hline \multirow[t]{5}{*}{ Obom (high transmission area) } & s2 & Unfractionated PBMCs & EHREHPKEY & 3D7/FVO \\
\hline & s3 & CD8 + enriched PBMCs & HFYKDNKYVK & $3 \mathrm{D} 7$ \\
\hline & s5 & CD8+ enriched PBMCs & $\begin{array}{l}\text { DVYRPINEHR } \\
\text { EHREHPKEY } \\
\text { MTLDEMRHFY }\end{array}$ & $\begin{array}{l}\text { 3D7 } \\
\text { 3D7/FVO } \\
\text { 3D7 }\end{array}$ \\
\hline & s6 & Unfractionated PBMCs & 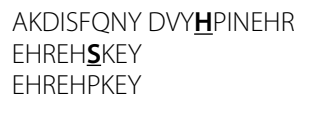 & $\begin{array}{l}\text { 3D7 } \\
7 \mathrm{G} 8 / \mathrm{FVO} \\
7 \mathrm{G} 8 \\
\text { 3D7/FVO }\end{array}$ \\
\hline & s7 & CD8 + enriched PBMCs & $\begin{array}{l}\text { AKDKSFQNY } \\
\text { DVY } \underline{\mathbf{H} P I N E H R} \\
\text { DVYRPINEHR }\end{array}$ & $\begin{array}{l}7 \mathrm{G} 8 \\
7 \mathrm{G} 8 / \mathrm{FVO} \\
3 \mathrm{D} 7\end{array}$ \\
\hline Legon (low transmission area) & S17 & CD8 + enriched PBMCs & DVYRPINEHR & 3D7 \\
\hline
\end{tabular}

The underlined amino acids are the polymorphic residues relative to the 3D7 variant. All sequences in this table gave positive IFN- $\gamma$ responses against the indicated PBMC fractions

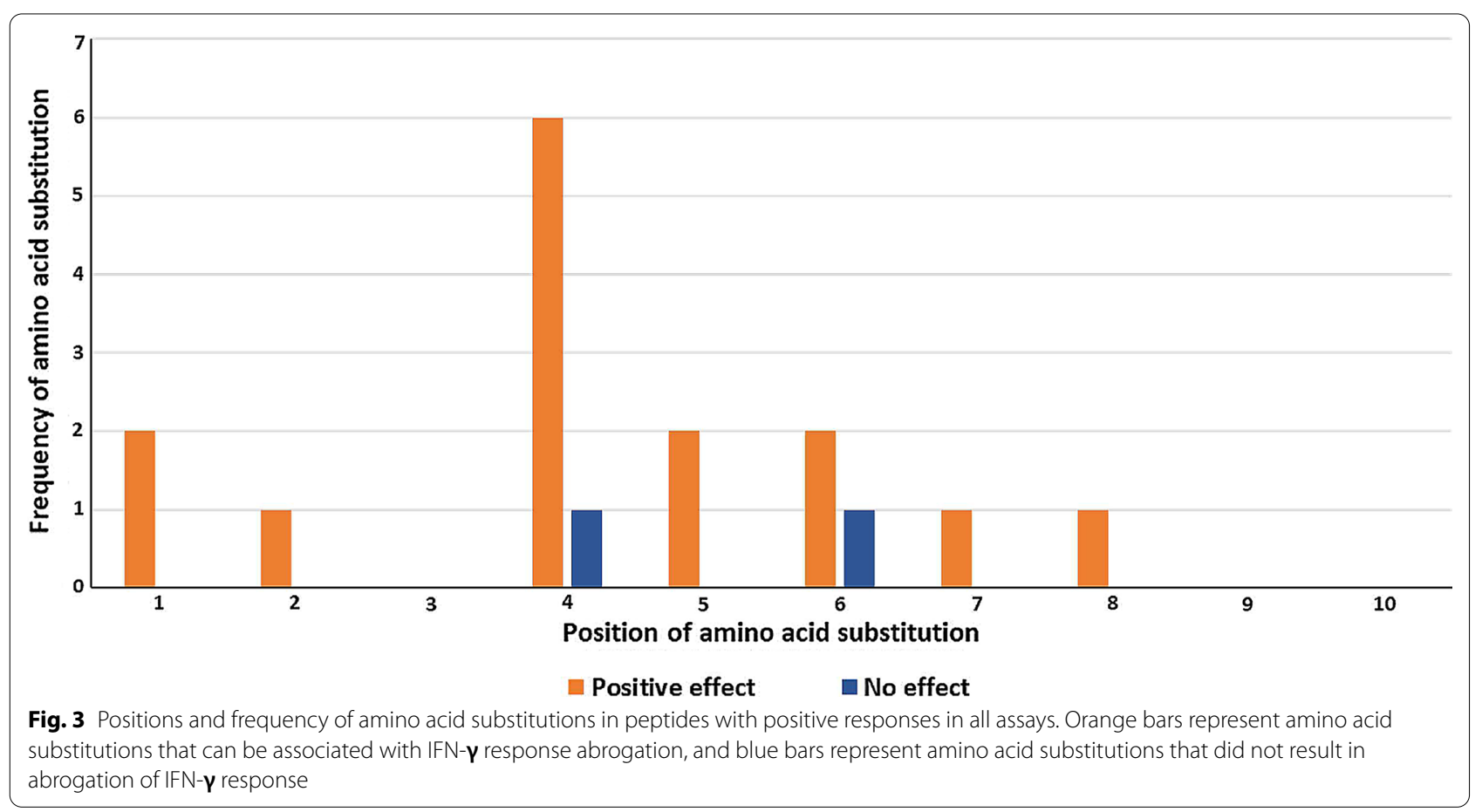

polymorphisms within either could potentially affect peptide recognition. In this study, we assessed the IFN- $\gamma$ induction potential of predicted polymorphic PfAMA1 peptides using a standard ELISpot assay and compared responses between individuals living in high and low malaria transmission areas.

Based on the peptides tested in this study, positive response frequency was higher in Obom relative to Legon. This may be a reflection of the fact that Obom is a high malaria transmission community, and subjects may have been exposed to multiple strains circulating in the community. The observation correlated with the expectation that high transmission most likely drives increased parasite diversity [37, 38]. The multiplicity of infection with parasites has generally been reported to be greater in high transmission areas compared with low transmission areas $[39,40]$. It is therefore expected that, persons living in high endemic communities would most likely have concomitant infection with diverse parasite strains, and this will result in the activation of several clones of $\mathrm{T}$ cells committed to responding to the different parasite strains. These $\mathrm{T}$ cell clones can survive for years [41] and 
upon re-infection, they can be recalled to mount immune attack on the new parasites. However, populations with low endemicity have a lower proportion of mixed-genotype infections, due to a low rate of superinfection, hence limited diverse clones of $\mathrm{T}$ cells. It must be noted that our earlier studies have picked up relatively higher numbers of anti-PfAMA1 responses with subjects recruited from the Legon area, but these studies have mostly tested PfAMA1 peptide pools that span the entire PfAMA1 sequence [32, 42, 43], while the current study tested a limited number of 15 single 9-10mer HLA-restricted minimal epitopes. Five of the eight $(63 \%)$ peptides that made positive responses in this study were 3D7 PfAMA1 variants (Table 2), and while this could suggest 3D7-like parasites to be the commonest circulating $P$. falciparum strains in the study communities, this observation could also simply be due to the fact that our selection of peptides for testing was based on epitope predictions for the 3D7 variant peptides.

For both study sites, the number of positive peptide responses increased upon CD8 + enrichment of PBMCs. We have previously reported similar findings with CSP peptides [36] and this could be due a depletion of $\mathrm{CD} 4+$ regulatory $\mathrm{T}$ cell subsets ( $\mathrm{T}$ regs) from PBMCs. Classically, $\mathrm{T}$ regs are a subset of $\mathrm{CD} 4+\mathrm{T}$ cells [44] and have been shown to increase in frequency during natural malaria infections [45-47]. The hallmark effect of Tregs are the impairment of $\mathrm{T}$ cell proliferation and cytokine production from other $\mathrm{T}$ cell subsets following engagement of their antigen-specific TCRs [41, 48, 49]. Hence depletion of these subsets may have led to removal of the stimulation restriction effect on CD8 $+\mathrm{T}$ cells, resulting in higher IFN- $\gamma$ activities in some subjects. It is worth noting that the subjects who made positive responses in assays with CD8 + enriched PBMCs (s3, s5, s7 and s17) did not make significant responses with the unfractionated PBMCs. Conversely, in subjects (s2 and s6) whose unfractionated PBMC were positive to some peptides, these effects were lost upon depletion of the CD4+fraction of PBMCs. On this basis, it is possible that these positive responses seen were $\mathrm{CD} 4+\mathrm{T}$ cell-specific although we could not confirm this due to insufficient cell numbers to test the CD4+ enriched PBMC.

Amino acid changes that affected peptide positivity in assays mostly occurred at residue positions 4,5 and 6 (Fig. 3). Jordan et al. [50] reported that substitutions that suitably change the spatial structure of peptides may enhance the immunogenicity of epitopes and improve the binding of TCRs to MHC ligands. Moreover, Calis et al. [51] have reported a significant impact of amino acid residue, weighted by the position at which it is found within the peptide, on the peptide's immunogenicity. They found that $\mathrm{T}$ cells have preference for aromatic and large residues and position 4 to 6 were shown to be most important especially in MHC class I antigen presentation to $\mathrm{CD} 8+\mathrm{T}$ cells. In this study, substitutions within the peptides that made positive responses mostly occurred within these positions.

In contrast, all peptides within two allelic sets elicited positive responses (Figs. 1 and 2), suggesting that the substitutions within these peptides, which occurred in positions 4 and 6 respectively (Fig. 3), were not enough to abrogate $\mathrm{T}$ cell response induction. Thus there was no clear relationship between amino acid residue substitutions within the peptide sequences and their effect on peptide positivity in assays.

This study was limited in two ways. First, very few peptides were tested. Using a greater number of predicted minimal epitopes could have increased our chances of identifying additional immunogenic peptides whose reactivities may be altered by the changes in variant parasite strains. Second, subjects from both sites were not HLA-typed hence the peptides tested were not selected on the basis of their predicted recognition of subjects' HLA types. Selection of peptides based on study subject HLA types may have increased the positivity rate of the tested peptides [13]. These findings are however relevant for the concept of constituting several $\mathrm{T}$ cell epitopes that are identified to be presented by specific HLA alleles into a multi-epitope vaccine for broad population use or as biomarkers for protective T cell immunity. Promiscuity in HLA recognition and binding by immunodominant peptides $[52,53]$ would contribute to the understanding of how this could work and make it possible for such potential multi-epitope vaccines to work in persons with HLA types that are not those upon which the vaccine epitopes were identified.

\section{Conclusion}

This study has provided some evidence that polymorphisms existing in peptides from malaria vaccine candidate antigens, like PfAMA1, can affect peptide recognition by $\mathrm{T}$ cells and hence the immune response that will be elicited. Furthermore, high endemicity which is expected to drive greater parasite diversity, may result in a broadening of the repertoire of $\mathrm{T}$ cells that can recognize specific peptides beyond what can be achieved with a whole parasite vaccine containing a single parasite strain. We can also infer the possibility of broad HLA recognition of peptides originally predicted to be presented by specific HLA alleles, and this could further strengthen the multi-epitope vaccine design concept. These findings will further our understanding of cellular immune mechanisms that govern anti-Plasmodium $\mathrm{T}$ cell responses and help direct the selection of peptides for inclusion in multi-epitope 
vaccines that can offer cross-strain protection as well as biomarkers for assessing protective $\mathrm{T}$ cell immunity.

\begin{abstract}
Abbreviations
PfAMA1: P. falciparum apical membrane antigen 1; CSP: Circumsporozoite protein; ELISpot: Enzyme-linked immunospot assay; HLA: Human leukocyte antigen; IFN-ү: Interferon-gamma; MHC: Major histocompatibility complex; NMIMR: Noguchi Memorial Institute for Medical Research; PBMC: Peripheral blood mononuclear cell; RDT: Rapid diagnostic test; Sfc/m: Spot forming Cells per million; TCR: T cell receptor; WHO: World Health Organization.
\end{abstract}

\section{Supplementary Information}

The online version contains supplementary material available at https://doi. org/10.1186/s12936-021-03900-1.

Additional file 1. Complete data for subjects whose PBMCs showed at least one positive peptide response. Peptide and positive control (con A) $\mathrm{sfc} / \mathrm{m}$ data are after subtraction of the corresponding medium only sfc/m for that subject.

Additional file 2. Representative sample of $C D 8+T$ cells enrichment confirmed by flow cytometry. Figure A shows the population of nonCD8 + cells (CD3 + CD8-) and CD8 + T cells (CD3 + CD8 +) before negative selection. Figure $B$ shows the population of non-CD8 + cells (CD3 + CD8-) and $C D 8+T$ cells $(C D 3+C D 8+)$ after negative selection.

\section{Acknowledgements}

We are grateful to study subjects from both sites for their participation in this study. We are also grateful to technical staff of the Immunology Department of Noguchi Memorial Institute for Medical Research for assistance with various aspects of PBMC cryopreservation and support for performance of assays.

\section{Disclaimer}

The views expressed in this article reflect the results of research conducted by the authors and do not necessarily represent the official policy or position of the Department of the Navy, Department of Defense nor the U.S. government.

\section{Copyright statement}

MS and EV are employees of the U.S. Government. This work was prepared as part of their official duties. Title 17, U.S.C., $\$ 105$ provides that copyright protection under this title is not available for any work of the U.S. Government. Title 17, U.S.C., §101 defines a U.S. Government work as a work prepared by a military Service member or employee of the U.S. Government as part of that person's official duties.

\section{Authors' contributions}

EAO, MS, MFO, KAK conceived and designed experiments; EAO, JKAT, AF, performed the experiments - EAO, JKAT, AF, KAK performed data analysis; $H G$, $M B, B P, M S, M F O, K A K$ contributed reagents/other resources; EAO, MS, KAK wrote the paper, MFO, BP, EV, AF contributed intellectually and reviewed the manuscript. All authors read and approved the final manuscript.

\section{Funding}

This study was funded by the Bill and Melinda Gates Foundation under the Postdoctoral and Postgraduate Training in Infectious Diseases Research program, awarded to the Noguchi Memorial Institute for Medical Research (Global Health Grant number OPP52155: Koram). Ebenezer Addo Ofori was also supported by a graduate thesis research fund from a World Bank African Centres of Excellence grant (ACE02-WACCBIP: Awandare).

\section{Availability of data and materials}

All data generated or analysed during this study are included in this published article.

\section{Declarations}

\section{Ethics approval and consent to participate}

The study received ethical approval from the Institutional Review Board of the Noguchi Memorial Institute for Medical Research (NMIMR), University of Ghana (NMIMR-IRB protocol number \# 024/15-16). The NMIMR IRB has a US Government Federal-wide Assurance (FWAA00001824) from the Office for Human Research Protections. Preceding enrolment, the study protocol was clarified to all subjects and written informed consent was sought from the study subjects before they participated in the study.

\section{Consent for publication}

Not applicable.

\section{Competing interests}

The authors declare that they have no competing interests.

\section{Author details}

${ }^{1}$ West Africa Centre for Cell Biology of Infectious Pathogens, Department of Biochemistry, Cell and Molecular Biology, College of Basic and Applied Sciences, University of Ghana, Legon, Accra, Ghana. ${ }^{2}$ Department of Immunology, Noguchi Memorial Institute for Medical Research, College of Health Sciences, University of Ghana, Legon, Accra, Ghana. ${ }^{3}$ Malaria Department, Naval Medical Research Center, Silver Spring, USA. ${ }^{4}$ La Jolla Institute for Allergy and Immunology, La Jolla, CA, USA. ${ }^{5}$ Henry M. Jackson Foundation for the Advancement of Military Medicine, Bethesda, MD, USA.

\section{Received: 8 June 2021 Accepted: 28 August 2021}

Published online: 10 September 2021

\section{References}

1. World malaria report 2020. https://www.who.int/publications-detail-redir ect/9789240015791. Accessed 26 Jun 2021.

2. World Health Organization. Global Technical Strategy for Malaria 2016-2030. Global Malaria Programme. 2015; 29.

3. Ubillos I, Ayestaran A, Nhabomba AJ, Dosoo D, Vidal M, Jiménez A, et al. Baseline exposure, antibody subclass, and hepatitis B response differentially affect malaria protective immunity following RTS, S/AS01E vaccination in African children. BMC Medicine. 2018;16:1.

4. Olotu A, Fegan G, Wambua J, Nyangweso G, Leach A, Lievens M, et al. Seven-Year Efficacy of RTS, S/AS01 Malaria Vaccine among Young African Children. N Engl J Med. 2016;374:2519-29.

5. Saul A, Lawrence G, Allworth A, Elliott S, Anderson K, Rzepczyk C, et al. A human phase 1 vaccine clinical trial of the Plasmodium falciparum malaria vaccine candidate apical membrane antigen 1 in Montanide ISA720 adjuvant. Vaccine. 2005.

6. Thera MA, Coulibaly D, Kone AK, Guindo AB, Traore K, Sall AH, et al. Phase 1 randomized controlled trial to evaluate the safety and immunogenicity of recombinant Pichia pastoris-expressed Plasmodium falciparum apical membrane antigen 1 (PfAMA1-FVO [25-545]) in healthy Malian adults in Bandiagara. Malar J. 2016;15:1-11.

7. Payne RO, Milne KH, Elias SC, Edwards NJ, Douglas AD, Brown RE, et al. Demonstration of the blood-stage plasmodium falciparum controlled human malaria infection model to assess efficacy of the P. falciparum apical membrane antigen 1 Vaccine, FMP2.1/AS01. Journal of Infectious Diseases. 2016;213:1743-51.

8. Sagara I, Dicko A, Ellis RD, Fay MP, Diawara SI, Assadou MH, et al. A randomized controlled phase 2 trial of the blood stage AMA1-C1/Alhydrogel malaria vaccine in children in Mali. Vaccine. 2009;27:3090-8.

9. Silvie O, Franetich JF, Charrin S, Mueller MS, Siau A, Bodescot M, et al. A role for apical membrane antigen 1 during invasion of hepatocytes by Plasmodium falciparum Sporozoites. Journal of Biological Chemistry . 2004:279:9490-6.

10. Osier FH, Weedall GD, Verra F, Murungi L, Tetteh KK, Bull P, et al. Allelic diversity and naturally acquired allele-specific antibody responses to Plasmodium falciparum apical membrane antigen 1 in Kenya. Infect Immun. 2010. 
11. Remarque EJ, Faber BW, Kocken $\mathrm{CH}$, Thomas AW. Apical membrane antigen 1: a malaria vaccine candidate in review. Trends Parasitol. 2008;24:74-84.

12. Huaman MC, Mullen GED, Long CA, Mahanty S. Plasmodium falciparum apical membrane antigen 1 vaccine elicits multifunctional CD4 cytokineproducing and memory T cells. Vaccine. 2009;27(38):5239-46.

13. Sedegah M, Kim Y, Peters B, McGrath S, Ganeshan H, Lejano J, et al. Identification and localization of minimal MHC-restricted CD8+T cell epitopes within the Plasmodium falciparum AMA1 protein. Malaria Journal. 2010;9(1):1-6.

14. Sedegah M, Hollingdale MR, Farooq F, Ganeshan H, Belmonte M, Kim Y, et al. Sterile immunity to malaria after DNA prime/adenovirus boost immunization is associated with effector memory CD8+T cells targeting ama1 class I epitopes. PLoS ONE. 2014;9(9):e106241.

15. Ganeshan H, Kusi KA, Anum D, Hollingdale MR, Peters B, Kim Y, et al. Measurement of ex vivo ELISpot interferon-gamma recall responses to Plasmodium falciparum AMA1 and CSP in Ghanaian adults with natural exposure to malaria. MalarJ. 2016;15:55

16. Chuang I, Sedegah M, Cicatelli S, Spring M, Polhemus M, Tamminga C, et al. DNA Prime/Adenovirus Boost Malaria Vaccine Encoding P. falciparum CSP and AMA1 Induces Sterile Protection Associated with Cell-Mediated Immunity. PLoS ONE. 2013;8(2):55571.

17. Kusi KA, Faber BW, Thomas AW, Remarque EJ. Humoral immune response to mixed PfAMA1 alleles; multivalent PfAMA1 vaccines induce broad specificity. PLOS ONE. 2009:4(12):e8110.

18. Jiang H, Li N, Gopalan V, Zilversmit MM, Varma S, Nagarajan V, et al. High recombination rates and hotspots in a Plasmodium falciparum genetic cross. Genome Biol. 2011:12:R33.

19. Dewasurendra RL, Jeffreys A, Gunawardena SA, Chandrasekharan NV, Rockett K, Kwiatkowski D, et al. Host genetic polymorphisms and serological response against malaria in a selected population in Sri Lanka. Malar J. 2018;17:473.

20. Kusi KA, Faber BW, Riasat V, Thomas AW, Kocken CHM, Remarque EJ. Generation of humoral immune responses to multi-allele PfAMA1 vaccines; effect of adjuvant and number of component alleles on the breadth of response. PLOS ONE. 2010:5:e15391.

21. Sedegah M, Peters B, Hollingdale MR, Ganeshan HD, Huang J, Farooq F, et al. Vaccine strain-specificity of protective hla-restricted class 1 P. falciparum Epitopes. PLoS ONE. 2016;11:e0163026.

22. Sant'Angelo DB, Robinson E, Denzin LK. Recognition of core and flanking amino acids of $\mathrm{MHC}$ class II-bound peptides by the $T$ cell receptor. European Journal of Immunology. 2002;32:2510-20.

23. Huseby ES, White J, Crawford F, Vass T, Becker D, Pinilla C, et al. How the T cell repertoire becomes peptide and MHC specific. Cell. 2005;122:247-60.

24. Zhang H, Lim H-S, Knapp B, Deane CM, Aleksic M, Dushek O, et al. The contribution of major histocompatibility complex contacts to the affinity and kinetics of T cell receptor binding. Sci Rep. 2016;6:35326.

25. Ekeruche-Makinde J, Miles JJ, van den Berg HA, Skowera A, Cole DK, Dolton $\mathrm{G}$, et al. Peptide length determines the outcome of TCR/peptide-MHCI engagement. Blood. 2013;121:1112-23.

26. Sidney J, Peters B, Frahm N, Brander C, Sette A. HLA class I supertypes: a revised and updated classification. BMC Immunol. 2008:9:1.

27. Nlinwe ON, Kusi KA, Adu B, Sedegah M. T-cell responses against Malaria: Effect of parasite antigen diversity and relevance for vaccine development. Vaccine. 2018;36:2237-42.

28. About Us |GA South Municipal Assembly. https://gsma.gov.gh/about.html. Accessed 21 Aug 2021

29. Ayanful-Torgby R, Quashie NB, Boampong JN, Williamson KC, Amoah LE. Seasonal variations in Plasmodium falciparum parasite prevalence assessed by varying diagnostic tests in asymptomatic children in southern Ghana. PLOS ONE. 2018:13:1-14

30. Amoah LE, Abagna HB, Akyea-Mensah K, Lo AC, Kusi KA, Gyan BA. Characterization of anti-EBA175RIII-V in asymptomatic adults and children living in communities in the Greater Accra Region of Ghana with varying malaria transmission intensities. BMC Immunol. 2018;19:34.

31. Climate in Madina. Average monthly snow and rainfall in Madina (Greater Accra ) in inches Transformational leader, visionary thinker, a non-conformist and a proud son of the land More Climate Information For Madina. 2019:1:1-7.

32. Dodoo D, Hollingdale MR, Anum D, Koram KA, Gyan B, Akanmori BD, et al. Measuring naturally acquired immune responses to candidate malaria vac cine antigens in Ghanaian adults. Malaria Journal. 2011.
33. Amoah LE, Abankwa J, Oppong A. Plasmodium falciparum histidine rich protein-2 diversity and the implications for PfHRP 2: Based malaria rapid diagnostic tests in Ghana. Malaria Journal. 2016

34. Karosiene E, Lundegaard C, Lund O, Nielsen M. NetMHCcons: a consensus method for the major histocompatibility complex class I predictions. Immunogenetics. 2012. https://doi.org/10.1007/s00251-011-0579-8.

35. Nielsen $M$, Andreatta M. NetMHCpan-3.0; improved prediction of binding to $\mathrm{MHC}$ class I molecules integrating information from multiple receptor and peptide length datasets. Genome Med. 2016;8:33.

36. Kusi KA, Aggor FE, Amoah LE, Anum D, Nartey Y, Amoako-Sakyi D, et al. Identification of Plasmodium falciparum circumsporozoite proteinspecific CD8+ T cell epitopes in a malaria exposed population. PLOS ONE. 2020;15:e0228177.

37. Koepfli C, Ross A, Kiniboro B, Smith TA, Zimmerman PA, Siba P, et al. Multiplicity and diversity of Plasmodium vivax infections in a highly endemic region in papua New Guinea. PLoS Negl Trop Dis. 2011;5:1-7.

38. Koepfli C, Felger I, Barnadas C, Mueller I, Rodrigues PT, Orjuela-Sánchez P, et al. Plasmodium vivax diversity and population structure across four continents. PLoS Negl Trop Dis. 2015;9:1-23.

39. Adjah J, Fiadzoe B, Ayanful-Torgby R, Amoah LE. Seasonal variations in Plasmodium falciparum genetic diversity and multiplicity of infection in asymptomatic children living in southern Ghana. BMC Infect Dis. 2018;18:432.

40. Babiker HA, Lines J, Hill WG, Walliker D. Population structure of Plasmodium falciparum in villages with different malaria endemicity in east Africa. Am J Trop Med Hyg. 1997;56:141-7.

41. Pennock ND, White JT, Cross EW, Cheney EE, Tamburini BA, Kedl RM. T cell responses : naive to memory and everything in between. 2020;37:273-83.

42. Anum D, Kusi KA, Ganeshan H, Hollingdale MR, Ofori MF, Koram KA, et al. Measuring naturally acquired ex vivo IFN- $\gamma$ responses to Plasmodium falciparum cell-traversal protein for ookinetes and sporozoites (CelTOS) in Ghanaian adults. Malar J. 2015;14:1-8.

43. Ganeshan H, Kusi KA, Anum D, Hollingdale MR, Peters B, Kim Y, et al. Measurement of ex vivo ELISpot interferon-gamma recall responses to Plasmodium falciparum AMA1 and CSP in Ghanaian adults with natural exposure to malaria. Malaria Journal. 2016;15(1):1-5.

44. Amy C. Hobeika, Michael A. Morse, Takuya Osada SP, H. Kim Lyerly and TMC. Regulatory T cells. Immunotherapy of Cancer: An Innovative Treatment Comes of Age. 2011;707:309-22

45. Kurup SP, Butler NS, Harty JT. T cell-mediated immunity to malaria. Nature Reviews Immunology. 2019;19(7):457-71.

46. Frimpong A, Kusi KA, Tornyigah B, Ofori MF, Ndifon W. Characterization of T cell activation and regulation in children with asymptomatic Plasmodium falciparum infection. Malar J. 2018;17:1-13.

47. Hansen DS, Schofield L. Natural Regulatory T Cells in Malaria: Host or Parasite Allies? PLoS Pathogens. 2010;6:e1000771

48. Torres KJ, Villasis E, Bendezú J, Chauca J, Vinetz JM, Gamboa D. Relationship of regulatory $T$ cells to Plasmodium falciparum malaria symptomatology in a hypoendemic region. Malaria Journal. 2014;13:1.

49. Nie CQ, Bernard NJ, Schofield L, Hansen DS. CD4+CD25+regulatory T cells suppress CD4+T-cell function and inhibit the development of Plasmodium berghei-specific $\mathrm{TH} 1$ responses involved in cerebral malaria pathogenesis. Infect Immun. 2007;75:2275-82.

50. Jordan KR, McMahan RH, Kemmler CB, Kappler JW, Slansky JE. Peptide vaccines prevent tumor growth by activating $T$ cells that respond to native tumor antigens (Proceedings of the National Academy of Sciences of the United States of America (2010) 107, (4652-4657)). Proc Natl Acad Sci USA. 2010;107:4788-9.

51. Calis JJA, Maybeno M, Greenbaum JA, Weiskopf D, De Silva AD, Sette A, et al. Properties of MHC class i presented peptides that enhance immunogenicity. PLoS Computational Biology. 2013;9:1.

52. Frahm N, Yusim K, Suscovich TJ, Adams S, Sidney J, Hraber P, et al. Extensive HLA class I allele promiscuity among viral CTL epitopes. EurJImmunol. 2007;37:2419-33.

53. Rao X, Hoof I, Costa Al, van Baarle D, Kesmir C. HLA class I allele promiscuity revisited. Immunogenetics. 2011;63:691-701.

\section{Publisher's Note}

Springer Nature remains neutral with regard to jurisdictional claims in published maps and institutional affiliations. 